\title{
The Design and Analysis of Home Automation Systems Based on MAC Address
}

\author{
Muhammad Aden Fahadi, ${ }^{1, *}$, Yuwaldi Away ${ }^{\mathrm{b}, 2}$, Ira Devi Sara ${ }^{\mathrm{b}, 3}$ \\ ${ }^{a}$ Magister Teknik Elektro, Fakultas Teknik, Universitas Syiah Kuala \\ Jalan Teungku Syech Abdurrauf No.7, Darussalam, Banda Aceh, 23111, Indonesia. \\ ${ }^{b}$ Magister Teknik Elektro, Fakultas Teknik, Universitas Syiah Kuala \\ Jalan Teungku Syech Abdurrauf No.7, Darussalam, Banda Aceh, 23111, Indonesia.

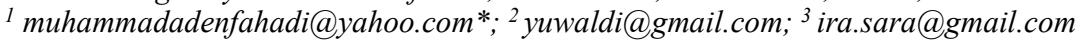 \\ * corresponding author
}

\begin{abstract}
Article history:

Accepted

Keywords:

Home Automation

MAC address

Wemos D1

Solenoid

Android

Home Automation is one of the advances in technology and communication by automating the control of electrical devices at home. With this method, home electronic devices can be controlled using a remote control system without having to touch the home appliances themselves. The development of the operating system on mobile devices gives birth to innovation and creativity in line with the needs of its users, from mere communication tools to information centers. One of the innovations in daily life is Home Automation, which allows control of electrical devices to save electricity consumption at home. That can be done remotely both in the same location or in other rooms with sensors and user interface design from Android to simplify monitoring. The Home Automation application communicates via MAC addresses on Android registered in Wemos D1, which Android can be used to control automatically, in this study using the Wemos D1 module as a brain or control center that receives data from Android for later processing to the lamp output, the motion sensor (PIR), DHT22 sensor, fan, and door lock by using a solenoid that can be controlled automatically from any sensors connected to the Wemos D1 microcontroller.
\end{abstract}

Copyright $(C 2020$ Politeknik Aceh Selatan. All rights reserved.

\section{Introduction}

The development of technology in a daily application makes it easy to turn on and off various electronic equipment such as lights, water heaters, and fans. The electronic devices can be controlled using a time-based program application, motion sensors, and automatic door locking. The technology that makes it easy for homeowners, who previously were electronic devices operated manually by everyone [1]. Home Automation can provide convenience, comfort, safety, savings, with technological sophistication. Automation using natural language, increasing interest in smart homes, improving the language, or collecting specific languages where input provided by the system allows users to interact with the system in various languages. The attraction of using this natural language is that smart home systems can understand the interaction and communication that humans use in everyday communication. This smart home can control electronic devices with only one central controller, Android, or control them when the user is not at home. Thus, it is vital to have a smart home automation system controlled with an Android device so that it significantly increase interest and develop technology for smart homes. Therefore, this research is inspired to design Home Automation by using event-driven methods to make it easier for humans to control these electronic devices. This electronic device can be controlled automatically in the room. The main objective is to realize savings in energy consumption and waste of excess operational costs. 
The development of smartphones technology is not only used for communication. The smartphone makes it easy for all community activities, especially in terms of communication, not only limited to calling or sending messages, in this case, but many smartphones also use the Windows mobile operating system, Linux, RIM Blackberry, and Android. Many online or offline applications make it easier for developers to create Android [2]. One example of the current problem is in the room, there are electronic items such as lights, fans, and door locks are generally still controlled manually, and the user must move a lot to activate these items. Therefore, this is a consideration for making this tool easier for humans to control electronic devices.

\section{The Proposed Method/Algorithm}

\section{A. Home Automation}

Home Automation is a smart home that has a system that can help control electronic equipment in the household so that it can simplify household work. Home Automation (HA) is an activity in building automation in a residential building or house to get a variety of convenience, comfort, and high efficiency in activities in the house [3]. To create such automation, a device that can work in an organized manner is needed where each device performs its private functions and simultaneously communicates with other devices in the system. Building an Energy Management System (BEMS) has been developed to improve occupancy's energy efficiency, which is seen as a comparison between energy costs and overall comfort. A BEMS optimizes control of energy supply and demand according to data [4].

\section{B. Wi-fi Technology}

Wi-fi is a wireless communication technology that uses radio technology, so wi-fi is a wireless device that acts as a bridge between wireless devices. Wi-fi technology has 2 main topology types, namely infrastructure and Ad-hoc. Ad-hoc allows a wi-fi network to function without a wireless router or access point. Ad-hoc mode is a method that allows wireless devices within range of the signal to communicate with peers without involving an access point [5].

\section{MAC Address}

MAC Address (Media Access Control Address) adalah sebuah alamat jaringan yang diimplementasikan pada lapisan data-link dalam tujuh lapisan model OSI, yang merepresentasikan sebuah node tertentu dalam jaringan. Dalam sebuah jaringan berbasis Ethernet, MAC address merupakan alamat yang unik yang memiliki panjang 48-bit (6 byte) yang mengidentifikasikan sebuah komputer, interface dalam sebuah router, atau node lainnya dalam jaringan. MAC Address juga sering disebut sebagai ethernet address, physical address, atau hardware address.

\section{Algoritma}

The subject of this research is the Wemos microcontroller-based automation system as a Home Automation controller, while the research object is an input variable, namely a digital signal (MAC Address) (X1), a temperature sensor (X2) and a motion sensor (X3), and an output variable in the form of a light dimmer (Y1), solenoid lock door (Y2) and fan (Y2). The following research objects are shown in Figure 1.

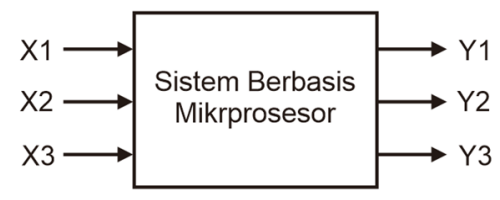

Fig 1. Object of research 
The initial design of home automation systems, door lock controllers, lights and fans using Wemos D1 microcontroller based on ESP8266 is composed of several block diagrams, namely adapters as power supplies, Wemos D1 modules as communication intermediaries, incandescent lamps as room lighting, dimmers as regulators light intensity, a DC motor as a fan, and a door lock solenoid as a lock.

\section{Method}

\section{A. Conceptual Design}

The prototype design of Home Automation is a system designed with the help of Wemos D1 microcontroller to integrate and control a device or equipment such as a fan, dim lights and illuminate lights using an AC light dimmer module (Pulse Width Modulation) PWM control, open and lock the door using a solenoid, and PIR as a motion sensor that serves to capture the movement in a room so that the lights remain in a state of life, LCD to display the temperature in the room, using the DHT22 sensor to measure the temperature in the room, while communication from Android and the sensor uses Wemos D1, for more he explained pay attention to Figure 2 below.

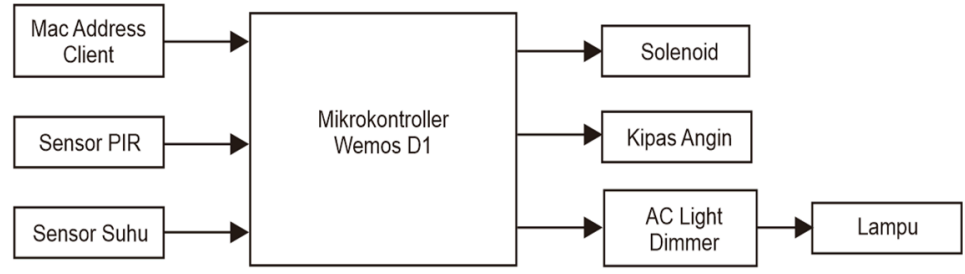

Fig 2. System Conceptual Design

\section{B. System Configuration}

The home automation configuration scheme using Wemos D1 in the prototype design of the house can be seen in Figure 3. In this condition, the house is installed Wemos D1 with Access Point mode as well as server, while the smartphone is a client. When the client is connected to the access point, the system reads the MAC address of the device. If the MAC address is the same as that registered, the system permits to turn on the system, but if it is not registered, then the system does not give device permission to turn on the system. Furthermore, when the device is disconnected with an access point, the system stops and not be able to run until it is connected to the registered device.

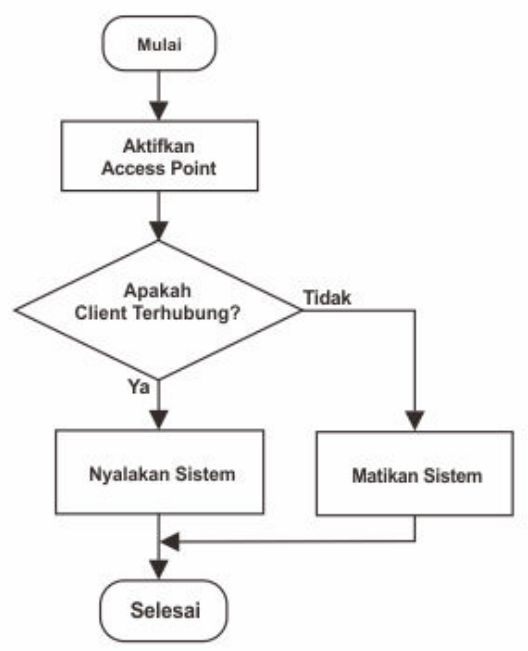

Fig 3. MAC Address-based SmartHome Schema 
Figure 4 is a wiring diagram of the SmartHome system. This system uses Wemos D1 as a microcontroller, with input in the form of a DHT22 sensor device as a temperature sensor and a PIR sensor as a motion sensor. At the output in the form of a fan device as a room temperature regulator, lights as lighting, solenoid door lock as a door lock, and LCD as a visualization of room temperature. While the 2 channel relay device as a switch setting and AC Light Dimmer as a lamp dimmer setting.

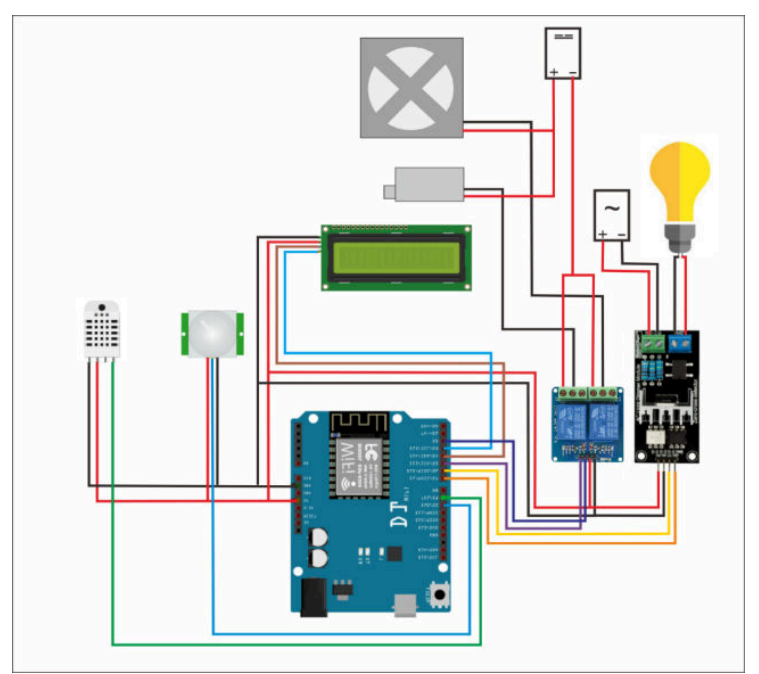

Fig 4. Home automation system series

The home automation configuration scheme above can be explained in Table 1 about the use of pins on Wemos and their information.

Table 1. Explanation of the use of a PIN on Wemos

\begin{tabular}{ccccccccc}
\hline No. & Pin & Sensor & Sensor & AC & I2C & \multicolumn{3}{c}{ Relay } \\
\cline { 9 - 10 } & & PIR & DHT22 & $\begin{array}{c}\text { Light } \\
\text { Dimmer }\end{array}$ & $\begin{array}{c}\text { Serial } \\
\text { LCD }\end{array}$ & $\begin{array}{c}\text { Solenoid } \\
\text { Door } \\
\text { Lock }\end{array}$ & $\begin{array}{c}\text { Kipas } \\
\text { Angin }\end{array}$ & $\begin{array}{c}\text { Stop } \\
\text { Kontak }\end{array}$ \\
\hline 1. & D10 & OUT & - & - & - & - & - & - \\
\hline 2. & D9 & - & OUT & - & - & - & - & - \\
\hline 3. & D7 & - & - & PWM & - & - & - & - \\
\hline 4. & D6 & - & - & Z-C & - & - & - & - \\
\hline 5. & D5 & - & - & - & - & IN1 & - & IN1 \\
\hline 6. & D4 & - & - & - & SDA & - & - & - \\
\hline 7. & D3 & - & - & - & SCL & - & - & - \\
\hline 8. & D2 & - & - & - & - & - & IN2 & - \\
\hline 9. & VCC & VCC & VCC & VCC & VCC & VCC & VCC & VCC \\
\hline 10 & GND & GND & GND & GND & GND & GND & GND & GND \\
\hline
\end{tabular}

\section{Working Mechanisms}

Figure 5 is a flowchart of the SmartHome system. When the device is connected to Wemos D1, the system reads the MAC address of the device and then compares it with the registered MAC address. If the same, the system turns on and gives access to the user. When the user is given access, the system gives a command to the door lock solenoid to open the door lock. Then the user enters the house, causing movement. The movement can be detected by a PIR sensor (motion detector). When motion is detected, the lamp starts to turn on using the $\mathrm{AC}$ light dimmer. The temperature sensor then 
reads the temperature in the room. If the temperature is more than $29^{\circ} \mathrm{C}$, the fan is turned on. If the room temperature is less or equal to $290 \mathrm{C}$, then the fan is stopped.

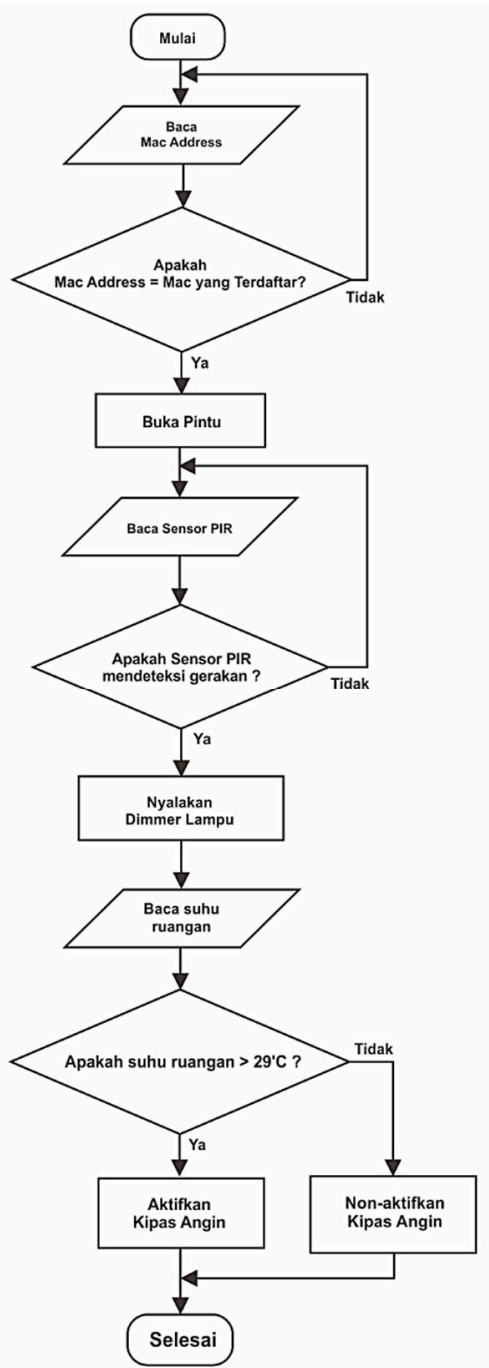

Fig 5. Flowchart of SmartHome Systems

\section{Program Structure}

Based on Figure 6, the program's structure has three subsystems: the input subsystem, the processing subsystem, and the output subsystem. In the input subsystem, there are three functions, namely the MAC address function, the motion detector function, and the temperature sensor function. In the processing subsystem, there are three functions, namely, the function of comparing MAC addresses, the function of reading motion, and the function of comparing room temperature. Whereas in the output subsystem, there is a lock door function, light dimmer function, and fan function. Each input is responsible for each output. In the MAC address function for the lock door function, in the motion detector function for the light dimmer function, and the temperature sensor function for the fan function. 


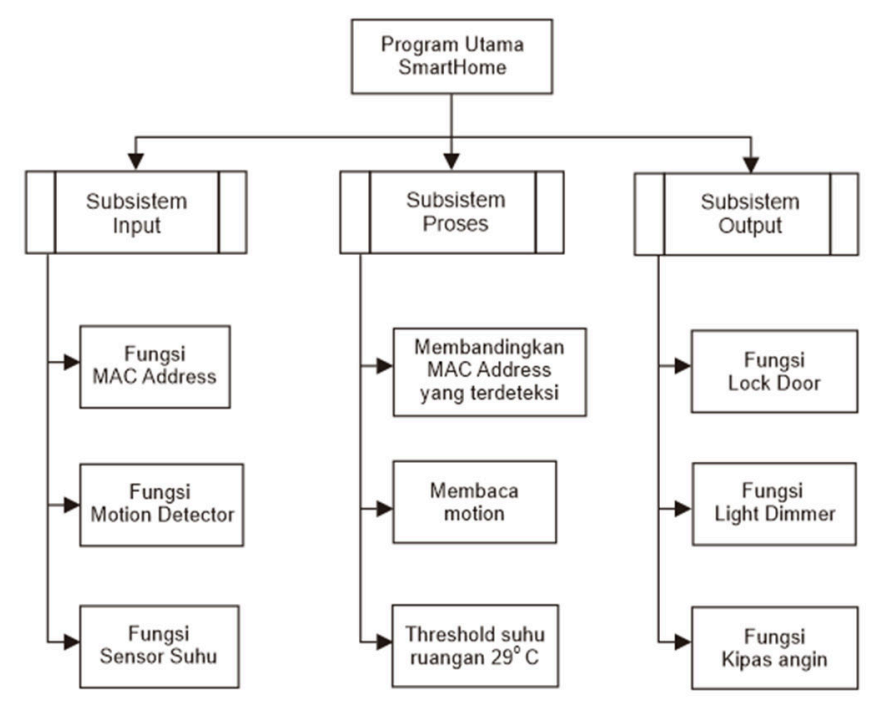

Fig 6. Program Structure

\section{Results and Discussion}

\section{A. Prototype Performance}

After conducting several stages of testing on the sensor module using a digital multimeter, it can be obtained several results in which the test data on incandescent lamps using AC power such as Table 2.

Table 2. Data after installing SmartHome with a 450W lamp load

\begin{tabular}{cccccc}
\hline Time & $\begin{array}{c}\text { Voltage } \\
\text { (Volt) }\end{array}$ & $\begin{array}{c}\text { Current } \\
\text { (Ampere) }\end{array}$ & $\begin{array}{c}\text { Power } \\
\text { (Watt) }\end{array}$ & $\begin{array}{c}\text { Energy } \\
\text { (kWh) }\end{array}$ & Explanation \\
\hline $13: 00$ & 220 & 0,09 & 19,8 & 0,003366 & $\begin{array}{c}\text { There are no } \\
\text { occupants }\end{array}$ \\
\hline $13: 10$ & 217,6 & 1,77 & 385,152 & 0,06884184 & There are occupants \\
\hline $13: 20$ & 217,8 & 1,77 & 385,506 & 0,13437786 & There are occupants \\
\hline $13: 30$ & 217,7 & 1,77 & 385,329 & 0,19988379 & There are occupants \\
\hline $13: 40$ & 217,1 & 1,78 & 386,438 & 0,26557825 & There are occupants \\
\hline $13: 50$ & 217,2 & 1,77 & 384,444 & 0,33093373 & There are occupants \\
\hline $14: 00$ & 217,5 & 1,78 & 387,15 & 0,39674923 & There are occupants \\
\hline $14: 10$ & 217,8 & 1,78 & 387,684 & 0,46265551 & There are occupants \\
\hline $14: 20$ & 217,9 & 1,77 & 385,683 & 0,52822162 & There are occupants \\
\hline $14: 30$ & 218,2 & 1,76 & 384,032 & 0,59350706 & There are occupants \\
\hline $14: 40$ & 218,3 & 1,77 & 386,391 & 0,65919353 & There are occupants \\
\hline $14: 50$ & 218,5 & 1,78 & 388,93 & 0,72531163 & There are occupants \\
\hline $15: 00$ & 218,7 & 1,79 & 391,473 & 0,79186204 & There are occupants \\
\hline $15: 10$ & 218,5 & 1,78 & 388,93 & 0,85798014 & There are occupants \\
\hline $15: 20$ & 218,2 & 1,78 & 388,396 & 0,92400746 & There are occupants \\
\hline $15: 30$ & 217,5 & 1,77 & 384,975 & 0,98945321 & There are occupants \\
\hline $15: 40$ & 217,5 & 1,75 & 380,625 & 1,05415946 & There are occupants \\
\hline $15: 50$ & 217,7 & 1,74 & 378,798 & 1,11855512 & There are occupants \\
\hline
\end{tabular}




\begin{tabular}{cccccc}
\hline Time & $\begin{array}{c}\text { Voltage } \\
\text { (Volt) }\end{array}$ & $\begin{array}{c}\text { Current } \\
\text { (Ampere) }\end{array}$ & $\begin{array}{c}\text { Power } \\
\text { (Watt) }\end{array}$ & $\begin{array}{c}\text { Energy } \\
\text { (kWh) }\end{array}$ & Explanation \\
\hline $16: 00$ & 217,7 & 1,75 & 380,975 & 1,18332087 & There are occupants \\
\hline $16: 10$ & 217,9 & 1,76 & 383,504 & 1,24851655 & There are occupants \\
\hline $16: 20$ & 218,4 & 1,76 & 384,384 & 1,31386183 & There are occupants \\
\hline $16: 30$ & 218,9 & 1,77 & 387,453 & 1,37972884 & There are occupants \\
\hline $16: 40$ & 219,2 & 1,77 & 387,984 & 1,44568612 & There are occupants \\
\hline $16: 50$ & 219,8 & 1,78 & 391,244 & 1,5121976 & There are occupants \\
\hline $17: 00$ & 219,4 & 1,79 & 392,726 & 1,57896102 & There are occupants \\
\hline
\end{tabular}

Based on Table 2, the test results are carried out for 4 hours with a 10-minute test interval, which is to obtain energy usage ( $\mathrm{kWh}$ ), the amount of power (Watts) 19.8 at 13.00 is converted to energy use $(\mathrm{kWh})$ by calculating in Equation (1).

$$
(19,8 / 1000) \times 0,17=0,003366
$$

A value of 0.17 is obtained from the sum by taking a 10-minute delay in which the data is taken for 4 hours, with 1 hour 60 minutes, then:

$$
60 / 10=0,1666667
$$

Then round up to 0.17 . The calculation in the 2 nd table row at 13.10 until 17.00 hours is the same for the sum.

Tabel 3. Data before install SmartHome with 450W

\begin{tabular}{cccccc}
\hline Time & $\begin{array}{c}\text { Voltage } \\
\text { (Volt) }\end{array}$ & $\begin{array}{c}\text { Current } \\
\text { (Ampere) }\end{array}$ & $\begin{array}{c}\text { Power } \\
\text { (Watt) }\end{array}$ & $\begin{array}{c}\text { Energy } \\
\text { (kWh) }\end{array}$ & Explanation \\
\hline $13: 00$ & 220 & 0,09 & 19,8 & 0,003366 & $\begin{array}{c}\text { There are no } \\
\text { occupants }\end{array}$ \\
\hline $13: 10$ & 220 & 2 & 440 & 0,078166 & There are occupants \\
\hline $13: 20$ & 220 & 2 & 440 & 0,152966 & There are occupants \\
\hline $13: 30$ & 220 & 2 & 440 & 0,227766 & There are occupants \\
\hline $13: 40$ & 220 & 2 & 440 & 0,302566 & There are occupants \\
\hline $13: 50$ & 220 & 2 & 440 & 0,377366 & There are occupants \\
\hline $14: 00$ & 220 & 2 & 440 & 0,452166 & There are occupants \\
\hline $14: 10$ & 220 & 2 & 440 & 0,526966 & There are occupants \\
\hline $14: 20$ & 220 & 2 & 440 & 0,601766 & There are occupants \\
\hline $14: 30$ & 220 & 2 & 440 & 0,676566 & There are occupants \\
\hline $14: 40$ & 220 & 2 & 440 & 0,751366 & There are occupants \\
\hline $14: 50$ & 220 & 2 & 440 & 0,826166 & There are occupants \\
\hline $15: 00$ & 220 & 2 & 440 & 0,900966 & There are occupants \\
\hline $15: 10$ & 220 & 2 & 440 & 0,975766 & There are occupants \\
\hline $15: 20$ & 220 & 2 & 440 & 1,050566 & There are occupants \\
\hline $15: 30$ & 220 & 2 & 440 & 1,125366 & There are occupants \\
\hline $15: 40$ & 220 & 2 & 440 & 1,200166 & There are occupants \\
\hline & & & & & \\
\hline
\end{tabular}




\begin{tabular}{cccccc}
\hline Time & $\begin{array}{c}\text { Voltage } \\
\text { (Volt) }\end{array}$ & $\begin{array}{c}\text { Current } \\
\text { (Ampere) }\end{array}$ & $\begin{array}{c}\text { Power } \\
(\text { Watt) }\end{array}$ & $\begin{array}{c}\text { Energy } \\
(\mathbf{k W h})\end{array}$ & Explanation \\
\hline $15: 50$ & 220 & 2 & 440 & 1,274966 & There are occupants \\
\hline $16: 00$ & 220 & 2 & 440 & 1,349766 & There are occupants \\
\hline $16: 10$ & 220 & 2 & 440 & 1,424566 & There are occupants \\
\hline $16: 20$ & 220 & 2 & 440 & 1,499366 & There are occupants \\
\hline $16: 30$ & 220 & 2 & 440 & 1,574166 & There are occupants \\
\hline $16: 40$ & 220 & 2 & 440 & 1,648966 & There are occupants \\
\hline $16: 50$ & 220 & 2 & 440 & 1,723766 & There are occupants \\
\hline $17: 00$ & 220 & 2 & 440 & 1,798566 & There are occupants \\
\hline
\end{tabular}

In Table 3, the data shows the usage of electric power before installing SmartHome. In this condition, there are two loads used, namely a lamp load of 100 Watts and an iron load of 350 Watts, so the total load used is $450 \mathrm{Watts}$. The use of power used starts at 13:00 with a power of 0.003366 $\mathrm{kWh}$ and ends at 17.00 with a total power usage of $1.798566 \mathrm{kWh}$. Data is collected every 10 minutes.

\section{B. Energy Savings}

After conducting several stages of testing on the sensor module using a digital multimeter, several results can be obtained in which the power saving data is tested on incandescent lamps by using AC power, as shown in Table 4.

Table 4. Energy-saving data

\begin{tabular}{ccccc}
\hline \multirow{2}{*}{ Time } & \multicolumn{2}{c}{ Energy Used } & \multicolumn{2}{c}{ Energy saving } \\
\cline { 2 - 5 } & $\begin{array}{c}\text { Before Installation } \\
(\mathbf{k W h})\end{array}$ & $\begin{array}{c}\text { After Installation } \\
\mathbf{( k W h )}\end{array}$ & $\begin{array}{c}\text { Difference } \\
\mathbf{( k W h )}\end{array}$ & $\mathbf{( \% )}$ \\
\hline $13: 00$ & 0,003366 & 0,003366 & 0 & 0 \\
\hline $13: 10$ & 0,078166 & 0,06884184 & 0,00932416 & 13,54 \\
\hline $13: 20$ & 0,152966 & 0,13437786 & 0,01858814 & 13,83 \\
\hline $13: 30$ & 0,227766 & 0,19988379 & 0,02788221 & 13,95 \\
\hline $13: 40$ & 0,302566 & 0,26557825 & 0,03698775 & 13,93 \\
\hline $13: 50$ & 0,377366 & 0,33093373 & 0,04643227 & 14,03 \\
\hline $14: 00$ & 0,452166 & 0,39674923 & 0,05541677 & 13,97 \\
\hline $14: 10$ & 0,526966 & 0,46265551 & 0,06431049 & 13,90 \\
\hline $14: 20$ & 0,601766 & 0,52822162 & 0,07354438 & 13,92 \\
\hline $14: 30$ & 0,676566 & 0,59350706 & 0,08305894 & 13,99 \\
\hline $14: 40$ & 0,751366 & 0,65919353 & 0.09217247 & 13,98 \\
\hline $14: 50$ & 0,826166 & 0,72531163 & 0,10085437 & 13,90 \\
\hline $15: 00$ & 0,900966 & 0,79186204 & 0,10910396 & 13,78 \\
\hline $15: 10$ & 0,975766 & 0,85798014 & 0,11778586 & 13,73 \\
\hline $15: 20$ & 1,050566 & 0,92400746 & 0,12655854 & 13,70 \\
\hline $15: 30$ & 1,125366 & 0,98945321 & 0,13591279 & 13,74 \\
\hline $15: 40$ & 1,200166 & 1,05415946 & 0,14600654 & 13,85 \\
\hline
\end{tabular}




\begin{tabular}{ccccc}
\hline \multirow{2}{*}{ Time } & \multicolumn{2}{c}{ Energy Used } & \multicolumn{2}{c}{ Energy saving } \\
\cline { 2 - 5 } & $\begin{array}{c}\text { Before Installation } \\
(\mathbf{k W h})\end{array}$ & $\begin{array}{c}\text { After Installation } \\
(\mathbf{k W h})\end{array}$ & $\begin{array}{c}\text { Difference } \\
(\mathbf{k W h})\end{array}$ & $\mathbf{( \% )}$ \\
\hline $15: 50$ & 1,274966 & 1,11855512 & 0,15641088 & 13,98 \\
\hline $16: 00$ & 1,349766 & 1,18332087 & 0,16644513 & 14,07 \\
\hline $16: 10$ & 1,424566 & 1,24851655 & 0,17604945 & 14,10 \\
\hline $16: 20$ & 1,499366 & 1,31386183 & 0,18550417 & 14,12 \\
\hline $16: 30$ & 1,574166 & 1,37972884 & 0,19443716 & 14,09 \\
\hline $16: 40$ & 1,648966 & 1,44568612 & 0,20327988 & 14,06 \\
\hline $16: 50$ & 1,723766 & 1,5121976 & 0,2115684 & 13,99 \\
\hline $17: 00$ & 1,798566 & 1,57896102 & 0,21960498 & 13,91 \\
\hline \multicolumn{5}{c}{ Total energy savings } \\
\hline
\end{tabular}

Based on Table 4, we can take the difference from the calculation by subtracting from Table 3 before SmartHome installation and Table 2 after SmartHome installation, as shown in Equation (3).

$$
\text { Before }(k W h)-\text { After }(k W h)=\text { Difference }(k W h)
$$

Based on Table 3, the total power savings of $2.75723969 \mathrm{kWh}$ are obtained. In calculating the percentage of energy savings using a formula like in Equation (4).

$$
\left|\frac{\text { Before }(k W h)-\text { After }(k W h)}{\text { After }(k W h)}\right| \times 100 \%=\% \text { Savings }
$$

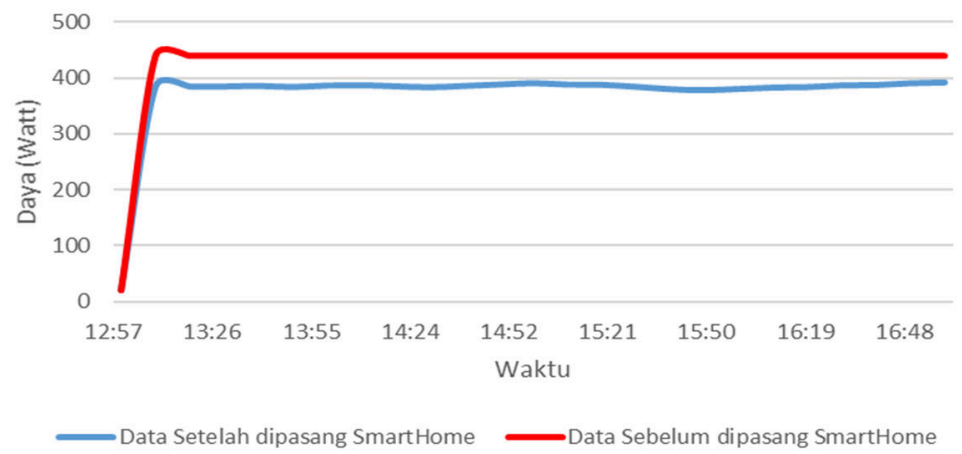

Fig 7. Power comparison graph

Based on Figure 7 shows a graph of power comparison between SmartHome before being installed and after SmartHome installed. It can be seen that the power used before SmartHome was set at 440 Watt, while after SmartHome was installed, the power was less than 440 Watt. Power measurements are carried out for 4 hours, starting from 13:00 until 17:00. The power used before installing SmartHome looks linear because the power used is constant. In contrast, the power before installing Smarthome is unstable due to the effect of using AC Light Dimmer. 


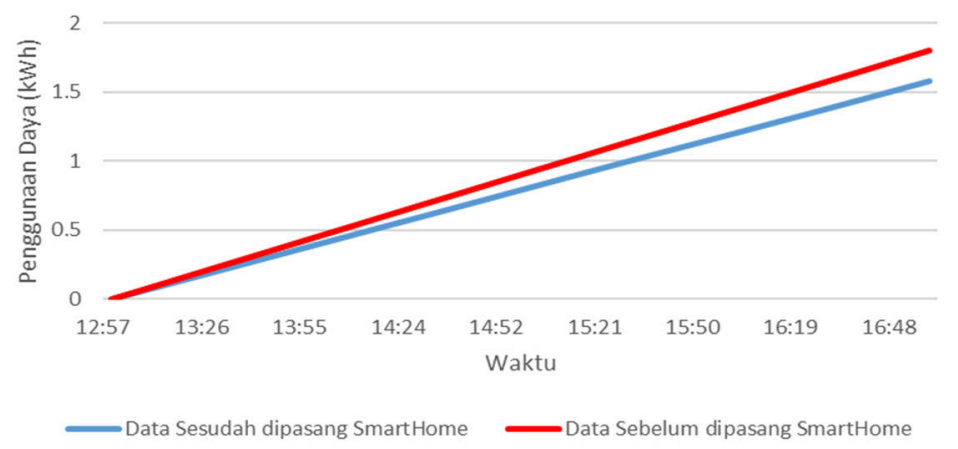

Fig 8. Energy usage comparison chart

Based on Figure 8 is a comparison graph between the use of power between before installation of SmartHome and after installation of SmartHome. The shape of the graph shows a linear increase. That is because the measured power usage by the $\mathrm{kWh}$ meter continues to increase from time to time. Although the data continues to increase, power usage after the installation of SmartHome is less than before the installation of SmartHome. The measurement data is carried out for 4 hours, starting from 13:00 until 17:00. Savings on SmartHome occur due to the effects of the AC Light Dimmer device. $\mathrm{AC}$ Light Dimmer functions as a regulator of dim or bright lights

\section{Conclusion}

Based on testing that has been done, the Home Automation system using Wemos as a MAC address-based control center can automatically turn off and turn off various devices. In the Home Automation system application, home load uses a power of 450 Watt to obtain energy savings of $2.75723969 \mathrm{kWh}$ with an average percentage of energy savings of $13.36 \%$.

\section{Acknowledgment}

I would like to thank the supervisor, Prof. Dr. Ir. Yuwaldi Away, M.Sc and Dr. Ira Devi Sara S.T., M.Eng.Sc and to the research assistants at PUSMATIK (Research Center for Automation and Robotics) who have assisted this research.

\section{References}

[1] Akkaya, K., Guvenc, I., Aygun, R., Pala, N., \& Kadri, A. (2017). "IoT-based occupancy monitoring techniques for energy-efficient smart buildings." In 2017 IEEE wireless.

[2] R. Missaoui, G. Warkozek, S. Bacha, S.Ploix, "Real-time validation of an optimization building energy management strategy based on power hardware in the loop tool," in 2012 3rd IEEE PES International Conference and Exhibition on Innovative Smart Grid Technologies (ISGT Europe), IEEE, 2012.

[3] E. Ahmed, and A. H. Karim, "Design and Implementation of a wi-fi Based Home Automation System," World Academy of Science, Engineering and Technology, vol. 6, pp. 1856-1862, 2012.

[4] W. Kastner, G. Neugschwandtner, S. Soucek, H.M. Newman, "Communication systems for building automation and control," Proc.IEEE 93 (June (6) ) (2005) 1178-1203.

[5] E. Ahmed, and A. H. Karim, "Design and Implementation of a wi-fi Based Home Automation System," World Academy of Science, Engineering and Technology, vol. 6, pp. 1856-1862, 2012. 